\title{
Reflections on the Teaching and Management of Higher Vocational Colleges
}

\author{
Wei Yao \\ (Dalian Vocational Technology College, Zip code: 116035, China)
}

\begin{abstract}
Key words: vocational colleges; teaching level; management work; comprehensive competitiveness
\end{abstract}

\begin{abstract}
The rapid development of vocational education has had an important impact on the speed of development of higher vocational colleges in China. In order to improve the level of education and teaching in higher vocational colleges and to maintain its good market competitiveness, it is necessary to implement relevant management work and evaluate the effect of different management work and deal with the problems . Based on this, this article discusses the education and teaching management of higher vocational colleges, which can make it be in stable development state and provide to guarantee for the cultivation of professional and technical talents .
\end{abstract}

\section{Introduction}

The effective implementation of education and teaching management in higher vocational colleges is conducive to maintaining good order of teaching management, reducing the incidence of problems of education and teaching, and promoting its own unique competitive advantage in the future development of higher vocational colleges. Therefore, in the course of practice, we should combine the practice of education and teaching management in higher vocational colleges, and discuss the relevant measures to improve the management level of the higher vocational colleges so as to ensure the effective implementation of the work, so as to inject the stable development of higher vocational colleges in China vitality. At the same time, vocational education and teaching management work smoothly, but also can achieve optimal allocation of resources.

\section{Clear the Goal of Personnel Training, Pay Attention to Education and Teaching Reform}

Higher vocational colleges play an important role in the cultivation of skilled talents in China. Therefore, in view of the lack of effectiveness of the education and teaching management of some higher vocational colleges, the level of education and teaching management needs to be improved. It needs the practical effect and efficiency of the teaching and management of higher vocational colleges in the course of practice, quality and other aspects of analysis. Then clear the goal of personnel training. At the same time, we should pay attention to its education and teaching reform, and enhance the related work in the practice of vocational colleges in the application of the effect. In addition, due to the large population, uneven regional economic development, employment pressure in different regions and other issues is existing, objectively described that we need to vigorously develop higher vocational education. On this basis, China's national education system will be more perfect, a variety of educational resources will be optimized allocation, so that the development of vocational education needs to speed up.

Vocational colleges can take actions from these aspects in a process of clear the goal of personnel training, pay attention to education and teaching reform process,: (1) emphasis on the use of physical integration of teaching methods, and select effective courses to strengthen the vocational skills of vocational training (2) to strengthen the education and teaching management in the implementation of the sense of reform, and improve the reform plan to further promote the correct understanding of the practice of education and teaching reform to give more attention, and provide reference to the education and teaching reform, (3) In the process of cultivating the skilled talents in vocational colleges, we should fully consider the degree of their cultural knowledge and practical ability, and highlight the main body of the students in the teaching of the training. Status, and 
strengthen the awareness of innovative personnel training, and then determine the appropriate personnel training objectives, improve the quality of vocational training personnel to meet the actual needs of different employers. At the same time, the implementation of practical teaching activities in vocational colleges also needs to curriculum architecture, curriculum content to give the necessary considerations. Under the guidance of effective personnel training objectives, the students 'actual needs and local economy are combined to ensure the balance of the curriculum structure, and give the objective evaluation of the students about their the specific performance in the practice of teaching activities, in order to promote the students' professional skills Able to get scientific training [1].

\section{Grasp the Rule of Education and Teaching Combined with the Actual Situation, Enhance the Level of Teaching Management}

Compared with the general higher education, the teaching and training of higher vocational colleges needs to pay more attention to the cultivation of skilled talents, which has its own characteristics in the aspects of students' quality, training objectives and curriculum contents. Therefore, in order to improve the level of education management in higher vocational colleges, it is necessary to ensure that vocational colleges can form a unique education and teaching management mode in the course of long-term practice, and need to be able to combine their own actual situation, master the law of education and teaching management level, and further broaden the existing teaching management space. To achieve such a development goal, the higher vocational colleges can take actions from the following aspects:

\subsection{Focus on the Use of Information Technology, Education and Teaching Management System to Achieve the Building of the System}

Under the new situation, the opportunities and challenges in the development of higher vocational colleges are coexisting. In the process of implementing the education and teaching management, it is necessary to strengthen the situation analysis in the process of grasping the law of education and teaching, pay attention to the use of information technology, realize education Teaching management organization system for the practice of management activities to carry out the foundation. (1) Combining the concept of higher vocational education, the author takes full account of the role of students in the teaching of practical education and the role of "double teacher", and applies the information technology to the daily education and teaching management work. (2) according to the education and teaching management and management activities need to carry out the requirements of the management subsystem at all levels to optimize the integration of information technology in order to support the formation of a powerful form of support for the development of education and teaching management system; education and teaching organization system, to achieve its education and teaching coordination and management [2].

\subsection{Pay Attention to Teaching Operation and Management, Strengthen the Construction of Teachers}

The effective grasp of the law of education and teaching in higher vocational colleges needs to be analyzed and summarized in the long - term management practice, which can promote the existing teaching and management work and optimize the working methods to meet the requirements of stable development of higher vocational education. Therefore, the vocational colleges need to pay attention to operation and management, the accumulation of more education and teaching management experience, enrich management content, enhance the applicability of management tools. At the same time, vocational colleges also need to strengthen the construction of teachers, introduce more high-quality teachers, do the assessment of teachers from the theoretical level, professional knowledge and other aspects of the comprehensive, and increase capital investment, improve education and teaching infrastructure, improving the management and teaching level of higher vocational colleges. 


\section{Improve the Personnel Training Program, Optimize the Teaching and Management of Education}

As an important part of the education and teaching management in higher vocational colleges, whether the formulation and implementation of the personnel training program is effective it is related to the effect of personnel training in higher vocational colleges, and is closely related to the level of teaching management. Therefore, in view of the lack of effectiveness of the personnel training program under the traditional education mode of higher vocational colleges, the education and teaching management is relatively backward and so on. It is necessary to improve the personnel training program on the basis of clear personnel training objectives and optimize the teaching and management of education, to give their work to carry out the necessary support. In the process of practice, we should start from these aspects: (1) to evaluate the comprehensive ability requirements of higher vocational talents in the new situation, from the aspects of training objectives, training mechanism, training methods and so on, to optimize the existing vocational training programs, and ultimately get an effective personnel training program. (2) to optimize the teaching and management of higher vocational colleges and universities, improve the teaching and management of higher vocational colleges under the influence of this kind of program, Making the quality of education and teaching management more reliable should start from the students' subjective initiative, the flexibility of management methods and so on[3].

\section{Innovative Education and Teaching Philosophy, Enhance the Management Mechanism Innovation}

At present, China's market economy is complicated, and there are various uncertain factors in the reform of vocational education, which objectively determines the necessity of emphasizing the concept innovation in the teaching and management of higher vocational colleges. (1) innovative education and teaching management system, the innovation driving force as the education and teaching management work plan to promote the power source, to promote its related management activities to achieve the new situation of the development requirements, and promote the comprehensive development. (2) the innovative ideas should immerse into the education and teaching management work, combined with the purpose of running a higher vocational school to ensure that education and teaching work (in the case of education and teaching), and to ensure that the education and teaching work (3) give the necessary incentives to the teachers and students who participate in higher vocational education and teaching innovation activities in order to enhance their level of innovation and awareness. At the same time, it should be from the perspective of innovation, vocational education management management in the management of the applicability of the assessment to enhance its management mechanism innovation [4].

\section{Conclusion:}

Under the current situation, vocational colleges occupy an important position in the part of vocational education in our country, and provide scientific guarantee for the training of skilled talents. Therefore, the future development of higher vocational colleges should pay attention to education and teaching work, flexible use of different working mechanisms, working methods, to promote its overall management level which can always be maintained at a higher level, to meet the new situation of vocational education development claim. At the same time, vocational colleges should analyze and deal with the existing problems in the application of their education and teaching work, and ensure the effectiveness of the management work.

\section{References:}

[1] $\mathrm{Yu}$ Xiaohong. Humanistic education under the view of higher vocational college students management work [J] .Journal of Weekly, 2016, (14). 
[2] Xian Yao,Research on Total Quality Management of Practical Teaching in Higher Vocational Colleges [J]; Journal of Sichuan Normal University (Natural Science Edition), ,2014,(03).

[3] Wen Li, Huang Yan, Ren Nan. Higher vocational education reform under the background of the practice of teaching management [J]. Education and Teaching Forum, 2012, (30).

[4] Wang Dong, Zhang Hui. Vocational education of students in the management of some of the thinking [J]. Takako (mid-year), 2013, (09). 